as an entirely novel form of navigation and for the precision bombing of enemy targets on and, sea or in the air, is now well known as one of the outstanding achievements of the War, in which scientific workers, engineers, industry and the Services have co-operated with complete success. This work brought in its train remarkable developments in the technique and output of valves, cables with novel dielectrics, cathode ray tubes and many other components. The facts that a modern battleship carries about fifty transmitting sets of various kinds, and many more receiving sets, and that a Lancaster bomber fully equipped may require about four hundred valves, accounts for the statement that during the last year of the War thirty-eight million thermionic valves were produced for the Services as compared with a peace-time demand of a quarter of a million.

There are many other electrical engineering applications which have been exploited to the full during the War, such as the clearing of fields of magnetic mines and the fitting of ten thoasand warships and merchant vessels with degaussing equipment, the improvement of searchlights and their automatic direction by radar control, and the lighting of ports, shipyards and other important open areas under conditions of severe restrictions.

Dr. Dunsheath was only able to make a passing reference to the importance of the corporate work of the Institution of Electrical Engineers, and to the teaching profession, in providing an adequate supply of trained and experienced personnel of all grades. Without the assistance of large numbers of trained. personnel, many of the engineering and scientific achievements of the electrical engineer during the War would never have come to fruition.

\section{SCIENTIFIC STUDY OF FELLMONGERING}

$\mathrm{T}$ HE wool trade and, later, the cloth trade are the two industries on which the wealth of medieval England was founded, and wool production is still one of the leading industries of the British Empire. Though large quantities of wool are taken from the living sheөp at the annual shearing, a good deal comes from slaughtered sheop. The handling of the sheepskin after flaying, and the separation of the wool from the pelt, are the tasks of the fellmonger, who in many cases is carrying out his work to-day by the same methods as those employed by his ancestors hundreds of years ago. Fellmongering, however, like a number of other ancient crafts, has now become the subject of scientific research. Bulletin No. 184, recently issued by the Council for Scientific and Industrial Research of Australia (Melbourne: Gov. Printer, 1945), describes a series of important fundamental investigations on the fellmongering process carried out by F. G. Lennox, Margaret Maxwell and W. J. Ellis.

There are, speaking very roughly, two types of sheөp farmed in Australia : the Merino sheөp, with long fine wool and, even at best, a poor pelt, and the crossbred sheep with shorter, coarser wool and a better pelt. There are also two general methods of de-wooling. The older process, with origins lost in antiquity, is known as 'sweating'-the sheepskins are hung in a warm moist atmosphere until the wool loosens and can be pushed off the pelt by the hand, the wool fibre coming away complete with root. The more recent process is 'painting'; the skins are covered on the flesh side with a thick cream of lime and a reducing agent, generally sodium sulphide, and the alkali plus reducing agent travel through the skin and cause the wool fibre to break off just above the root. The painting process therefore leads to a slight shortening of the fibre, and the total loss of weight from this cause is sufficient to keep the older sweating process in being for Merino sheepskins, in spite of the considerable damage frequently done to the pelt, and the foul odour of the sweating chambers.

The present pamphlet contains twelve papers describing studies on wool-loosening by the sweating process, the effect on the pelt not being included. It is interesting that the foundation of the work is the development of a quantitative method for measuring the force required to detach a standard staple from the pelt. With this tool in the hands of the investigator, it becomes possible to study, with some accuracy, the effect of varying conditions on the rate at which the wool root is loosened from its base.

The active agents in the sweating process are bacteria; an ærobe, an atypical strain of Proteus vulgaris designated No. 7, being the dominant woolloosening organism, though three or four other species also have the same effect. No. 7 exists sparsely at the wool roots at the start of the sweating process, and freely when the wool is ready to pull. The agents of putrefaction which damage the pelt are anærobes. Many skins from up-country kills are dried for transport and have to be soaked back by the fellmonger before they ean be sweated. Studies of this soaking operation show that the soak-water is completely de-oxygenated, a condition which oncourages the growth of putrefactive anærobes. This, however, does not appear to inhibit the growth of No. 7 in the sweating chambers, and oxygenating the soak-water does not accelerate wool-loosening.

During sweating a large amount of ammonia is produced. Ammonia itself has a wool-loosening action, but the accumulation of ammonia tends to inhibit bacterial wool-loosening. The action of ammonia is due to the $\mathrm{NH}_{3}$ molecule. Aliphatic amines have a similar effect, though this diminishes with increasing size of the molecule, quaternary ammonium compounds having little activity. Lipid solvents similarly have a wool-loosening action, while reagents causing dehydration, such as acetone and solutions of sodium chloride, and even drying, have a wool-tightening action. Conditions which cause tissue-swelling also cause tightening, probably because the hair-bulb cannot pass up the follicle.

The impression left on the reader of the twelve papers is of work well planned, well executed and well reported. An interesting development of the research is a new method of de-woolling the numerous small scraps from the edges of skins treated by the painting process, as well as shanks and head pieces. In these the scraps of pelt have no commercial value, and it has been shown that by subjecting them to heat treatment at $65^{\circ} \mathrm{C}$. the skin tissues can be completely hydrolysed by proteases prepared from a bran culture of Aspergillus flavus-oryzae or by papain, leaving the wool undamaged.

The volume well illustrates how even the oldest craft can be improved by an understanding of its scientific basis, and further developments will be awaited with great interest.

D. JORDAN LLOYD. 